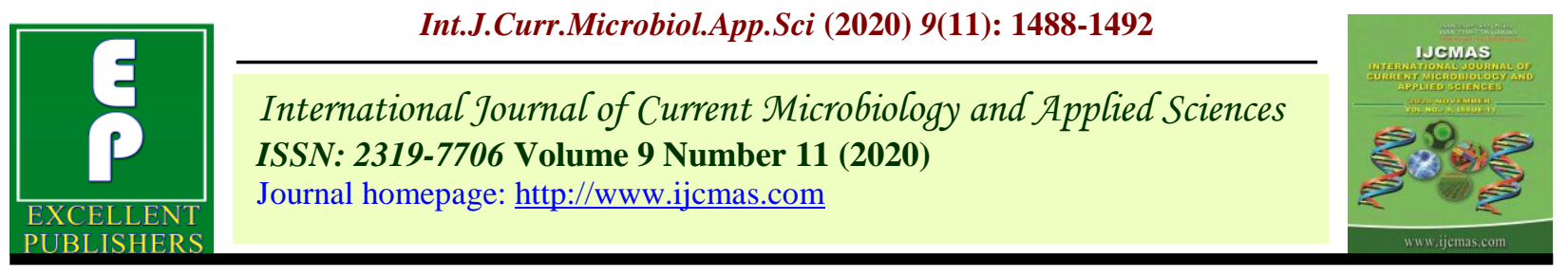

Review Article

https://doi.org/10.20546/ijcmas.2020.911.176

\title{
Terrace Gardening: A Way to Strengthen Mental Health
}

\author{
Kalyan, Deepak Sing, Veenit Pateer, Yudhvir, Nithin Sai Krishna and Homraj Sahare*
}

School of Agriculture, Lovely Professional University, Jalandhar-Delhi G. T. Road, Phagwara, Punjab, India

*Corresponding author

\section{A B S T R A C T}

\section{Keywords}

Terrace garden, Plants

Article Info

\section{Accepted:}

12 October 2020

Available Online:

10 November 2020
Terrace garden is any garden on the roof top. It have decorative benefits, roof planting may provide fresh horticulture produce, temperature control, hydrological benefits, architectural enhancements, habitats or corridor for wild life and recreational. According to housing development authority of India almost $90 \%$ of houses have flat roof tops. Well those can be effectively bought for aesthetic purpose. Roof gardening industry can be effective in making the paucity in vegetable availability in populous nation like India .Thus roof gardening can be shortcut for the urban greening any nature well in advance while increasing horticulture yield and mental health.

\section{Introduction}

India is a country with a population of around $138.40 \mathrm{Cr}$ out of which around $34.47 \%$ lives in urban areas away from greenery and now amidst COVID-19 we all are stuck at our home and even some of us are feeling depressed as we are not used to at being home and we are running out of options to what to do to come out of depression so one think all of us can do terrace gardening as we all have terraces which are empty. Gardening will not alone fill that vanity but also helps us in recovering from depression. Gardening is a good hobby to relieve from stress and to have a good body exercise and increase the blood flow in the body. But nowadays we all live in jungle but a concrete jungle. No doubt City life gives us all necessities which we need for Living a good life which is why people are attracted towards urbanes. Cities are crowded with buildings, routes, Multiplex etc. (Vazhacharickal, 2014), which all are sources of pollution. The places are so crowded that it's impossible to plant a single tree Let alone a garden to refresh our mind, body and soul. No doubt there are parks but in our so tightly scheduled life no one has time to hang in park. So think of your own garden where you can grow all plants of your taste. A place where you can sit in your free time and have a cup of tea - Terrace garden is the best solution. Terrace garden is an urbane feature. Almost everyone has a terrace/balcony which is empty so why don't we fill it with a beautiful terrace garden. Terrace garden is not 
only a garden it is an experience. Gardening along with hand grown vegetables and fruits which are totally organic and healthy to eat. In Terrace Garden you can grow vegetables/efflorescence/fruits in containers or raised beds or on vertical walls or you can just have a great green landscape with a beautiful sit out and feel blessed. Apart from this, terrace garden will also protect our building from absorbing heat hence result in low electricity bill also improve the air quality (Getter and Rowe 2006; Snodgrass and Snodgrass, 2006; Luckett, 2009).

\section{History}

The first known chronicled reference to a rooftop garden is the stone sanctuaries in the district of Mesopotamia (Patel et al., , 2019). Developments in Mesopotamia fabricated rooftop garden a large number of years back on the arrivals of ziggurat, or ventured pyramids of Egypt. The following known replacement to the rooftop is the wall hanging Gardens of Babylon worked by the farsi around the 500 B.C. The rooftop cultivates alongside being a visual enjoyment cooled the hot scenes and gave greenery. The medieval Egyptian city of Fustat had many high-rise buildings that NasirKhusraw in the early 11th century mentioned as rising up to 14 stories, with roof gardens on the top story complete with ox-drawn water wheels for irrigating them. Among the seven wonders of the ancient world, The Hanging Gardens of Babylon were one of them.

\section{Plant species selection}

During selection of plant species for terrace garden we should look the type of terrace present, climate and weather conditions in that particular zone and also select plant species in which way you are going to grow whether in pots, beds, bags and containers but generally large containers are preferred because plants grow easily in them. While selection of plants environment and natural segments have a huge activity. Real assurance of plant species guarantees perseverance of plant species. Plant species like flavors, grasses, perennials and trees make the housetop look like ordinary natural surroundings. If you are new to gardening and don't have any farming background grow vegetables which grows fast and they don't waste time with much undertakings such as Tomato (Solanum lycoperscium) Fenugreek (Trigonella foenum-graecum), Coriander (Coriandrum sativum), spinach (Spinacia oleracea), Egg plant (Solanum melongena), okra (Abelmoschus esculentus) pea (Pisum sativum) Cucumber (Cucumis sativus) etc. Mostly vegetables seeds are sown in a depth of 3-5 CM and $25-30 \mathrm{~kg}$ of vegetables can be produced in 1 square meter area in a year. If you are willing to create awesome blooms on your Roof garden you can grow Marigold (Calendula officinalis), Begonia (Begonia $x$ semperflorens-cultorum), Petunia (Petunia $\times$ atkinsiana) pansy (Viola tricolor var. hortensis) Hydrangea(Hydrangea macrophylla), Dianthus (Dianthus caryophyllus), Tulip bulbs (Tulipa),Hibiscus (Hibiscus rosa-sinensis) and Rose (Rosa) which comes in varieties can also be grown and also Snake plant (Dracaena trifasciata) Money plant (Epipremnum aureum) Song of india (Dracaena reflexa), Aloevera (Aloe barbadensis miller) etc.

Plant species like Ferns, vines, Lipstick plant are recommended for vertical garden. We can also grow herbs like lemon grass (Cymbopogon) which has several benefits like boosting nervous system and reducing fever and also Mint (mentha) can be grown which cures stomach related problems. If your terrace is large you can grow trees like pomegranate (Punica granatum), citrus trees, Guava (Psidium guajava) etc and 2-3ft pots which are round in shape are best for growing 
of tress on your terrace and trees should be pruned regularly. Grasses like bermuda grass (Cynodon dactylon), zoysia grasses can be grown for making you terrace look greener.
Plants species selection can also be done according to summer and winter season. Vegetables, flowers, fruits can be preferred according to the season (Table 1 and 2).

Table.1 Plant species recommended growing during winter season

\begin{tabular}{|c|c|c|c|}
\hline S.no & vegetables & Fruits & Flowers \\
\hline 1. & Tomato & Orange & Petunia \\
\hline 2. & Beans & Lemon & Pansy \\
\hline 3. & Spinach & Pomegranate & Calendula \\
\hline 4. & Radish & Cherries & Antirrhinum \\
\hline 5. & Carrot & Guava & Dianthus \\
\hline 6. & Fenugreek & Date & Marigold \\
\hline
\end{tabular}

Table.2 Plant species recommended growing during summer season

\begin{tabular}{|c|c|c|c|}
\hline S. no & Vegetables & Fruits & Flowers \\
\hline 1. & Brinjal & Muskmelon & Bougainvillea \\
\hline 2. & Chilli & Watermelon & Rose \\
\hline 3. & Lady finger & Orange & Gaillardia \\
\hline 4. & Bottle gourd & Sugarcane & Hydrangea \\
\hline
\end{tabular}

Plant selection is also dependent on factors such as

Weight of pot and plant species your terrace can manage

Plant improvement rate

Price of plant species in that particular area Plant species susceptibility to contamination Creating medium significance and it's piece Housetop height

\section{Cost of construction}

Cost of construction of terrace garden generally varies. If $\mathrm{u}$ wants to install terrace garden for commercial purpose the installation cost must be higher and if $u$ want to install terrace garden for subsistence purpose then the installation cost will be lesser.

Cost of Terrace garden also depends upon whether your terrace garden has automatic or manual systems. If $\mathrm{u}$ wish to install terrace garden at one time it will cost you more but if you're having financial problems you can invest little amount every month according to your money related condition. It will even cost you less if you use reused containers for terrace garden (Table 3).

Cost of construction of terrace garden moreover depends upon

Size of your Roof

Labour cost for civil work

Transportation cost

Saplings, seeds, containers cost in your Locality

Creating medium used for mix

Cost of geotextile membrane and drainage cells

Water framework system used for watering the plants whether it is manual or customized, etc. 
Table.3

\begin{tabular}{|l|l|l|}
\hline S. no & Particulates & Cost in Rs \\
\hline 1. & Pots & 50-500 Rs \\
\hline 2. & Plastic bags & $8-10 \mathrm{Rs}$ \\
\hline 3. & Cocopeat 5kg (Expands to 75L) & $279 \mathrm{Rs}$ \\
\hline 4. & Vermicompost 5kg & $399 \mathrm{Rs}$ \\
\hline 5. & Seeds & $15-20 \mathrm{Rs}$ \\
\hline 6 & Seedlings & 50-100 Rs \\
\hline 7. & Grotextile membrane & 40Rs/Square meter \\
\hline 8. & Labour cost for civil work & 80-100 Rs/sq.ft \\
\hline
\end{tabular}

In conclusion the terrace gardens are low input and high input returns in terms of crop and mental health. Most of the inputs are organized from the regionally out there resources- relations as workforce, organic compost made up of waste, bio-pesticides, nutrient recycling etc. Multiple use values of merchandise out there from gardens make home agriculture economically viable possibility. Most of the work involved in terrace garden construction is actually focused on the roof. Prior to installation, the roof and structure must be inspected for durability, modified for water protection, and be subjected to a flood test to make sure a watertight seal. Proper selection of plant species for terrace gardening is most important one we need to select the species according to your local home conditions and availability.

We can achieve maximum yield by panting vegetables crops by maintaining proper conditions like providing green shade nets are suggested for vegetable crops for proper light intensity. Create an ideal theme; choose plants as per design, to make beautiful landscapes. Don't be more excited to grow all the plants at the initial phases. Make an inventory of the plants you're getting to grow and grow one by one and arrange them within the terrace according the warmth and lightweight requirements. Soil with sand and vermicompost to make it more fertile and well drained. After the season, add some mild organic fertilizers with essential nutrients. As the rains wash away the nutrients in the soil. Terrace gardening needs regular watering, in summer water the plants twice a day. So through terrace gardening we can grow many plants like vegetables plants tomato, chilli, brinjal and some cucurbits plants. Ornamental and floral plants like Syngonium, Chinese evergreen, Jade Plant, PotMum (Chrysanthemum morifolium), Mogra, weeping fig etc. Annual floral plants like rose, marigold, petunia, salvia etc. Leafy vegetables like mint, fenugreek, spinach etc. Terrace gardens give pleasure to city dwellers and provide an opportunity for enhancing creativity as well psychological benefits. In addition, they change the visual appearance of the building, screening from neighbors, and conceal unwanted pipeline and unappealing scenery. Suspicion about the quality of vegetables available in urban markets and recycling of household waste is that the main motivation for these farming.

\section{References}

Getter, K.L. and Rowe, D.B. (2006). The role of extensive green roofs in sustainable development. Hort Science 41(5): 12761285.

Luckett, K. (2009). Green roof construction and maintenance (McGraw-Hill Companies, Inc., Ohio). 
Patel, A., Yadav, $\mathrm{R}$ and Singh Bhagirathi (2019). Study on terrace garden. International Journal of Trend in Research and Development, 6(1) 71-74.

Snodgrass EC and Snodgrass LL. (2006). Green roof plants: a resource and planting guide (Timber Press, Massachusetts).
Vazhacharickal, (2014). Balcony and terrace gardens in urban greening and local food production: scenarios from Mumbai metropolitan region ( $\mathrm{mmr}$ ), India. International Journal of Food, Agriculture and Veterinary Sciences, 4(2): 149-162.

\section{How to cite this article:}

Kalyan, Deepak Sing, Veenit Pateer, Yudhvir, Nithin Sai Krishna and Homraj Sahare. 2020. Terrace Gardening: A Way to Strengthen Mental Health. Int.J.Curr.Microbiol.App.Sci. 9(11): 1488-1492 doi: https://doi.org/10.20546/ijcmas.2020.911.176 